Nijssen, J., Nyssen, J., 2011. Pre-industrial headstones across the continental North Sea plain. Journal of Historical Geography, 37 (3): 273-287.

\title{
Pre-industrial headstones across the continental North Sea plain
}

\author{
Jaak Nijssen $^{\dagger, a}$, Jan Nyssen ${ }^{\text {,** }}$ \\ ${ }^{a}$ Veurserveld 4, B-3790 Sint-Martens-Voeren, Belgium \\ ${ }^{b}$ Department of Geography, Ghent University, Krijgslaan 281 (S8), B-9000 Ghent, \\ Belgium \\ * Corresponding author: Jan.Nyssen@UGent.Be
}

\begin{abstract}
This paper examines the spatial and temporal distribution of grave headstones in the relatively homogeneous North Sea plain and adjacent regions during the seventeenth and eighteenth centuries, as well as the various lithological, cultural, religious and transportation factors influencing this distribution. Findings from close inspection of cemeteries across the study area were complemented with data from existing surveys. The larger part of the production of headstones was for local consumption. High densities of cruciform (Catholic) headstones in the Boulonnais and in most of the ArdennesRhenish massif are illustrated with the cases of the Berwinne and Vesdre headstone production workshops. Beyond concentrations along the Meuse and Rhine rivers, there is a large area stretching from northern France to north-west Germany in which no headstones can be found (with the notable exception of a few Jewish cemeteries). Beyond this area devoid of headstones, the Marsh Islands and adjacent continental areas again have high densities (more than 1 headstone per $\mathrm{km}^{2}$ ), occurring in two well-differentiated clusters. One cluster contains simple poles in Belgian Palaeozoic limestone in NorthHolland and the West-Frisian islands, and the other cluster, on the German and Danish Marsh Islands, holds richly-decorated tablets made in sandstone from the Weserbergland. The headstones on the Marsh Island, a unifying cultural element in this UNESCO world heritage area, bear witness to the significance of a lucrative whaling activity and the intense trade that developed despite political, religious and linguistic differences across the region.
\end{abstract}

Key words: gravestone, cemetery, grave cross, low countries, Marsh Islands, stone trade, Palaeozoic limestone

Many headstones dating from the seventeenth and eighteenth centuries have survived in Europe (Figure 1). The evidence concerning the dates of these upright standing grave markers, or steles, is relatively abundant and reliable. From the sixteenth century, dates were increasingly used on various items of material culture across Europe, such as church bells. ${ }^{1}$ Selecting the continental North Sea plain (a total area of $130,000 \mathrm{~km}^{2}$ ) as a focus for this study allows us to analyse the distribution of headstones, as well as the lithologies used for them, in a relatively homogeneous and level region with a linear source area on

\footnotetext{
${ }^{1}$ H. Mytum, Materiality and memory: an archaeological perspective on the popular adoption of linear time in Britain. Antiquity 81 (2007) 381-396.
} 
one side (the Rhenish-Ardennes massif), and transport routes (rivers) stretching away from it. In addition to questions relating to production and transport, the turbulent history of the period, including schisms in Christianity and devastating conflicts such as the Thirty Years' War, will also be considered. ${ }^{2}$

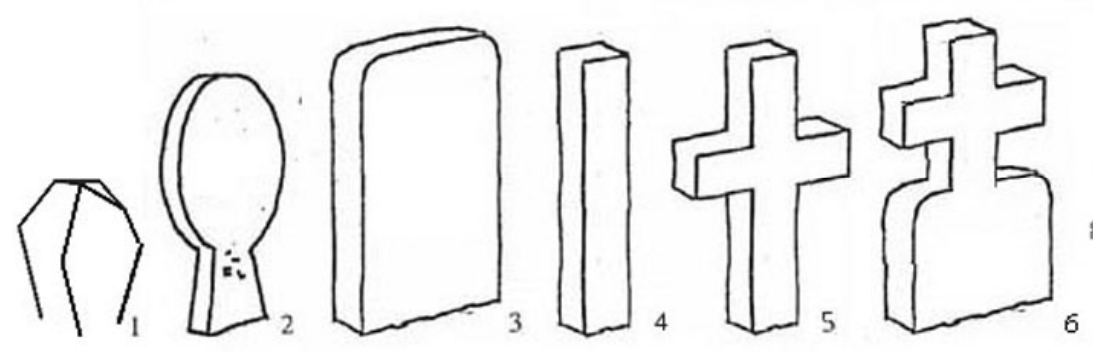

Figure 1. Basic types of headstones. 1: boulder; 2: discoid; 3: tablet; 4: pole; 5: cruciform; 6: composite.

Headstones belong to a range of memorial objects, including epitaphs, slabs, tombs, catafalques or tombs inside churches, most of which tend to be associated with a higher class of sculpture. Headstones themselves were generally used for memorialising lives in the vernacular world, especially for men of a higher social standing such as the miller, the baker, the better-off farmer, the judge and the sheriff. In terms of the techniques by which they were made, headstones have much in common with baptismal fonts, way crosses, milestones or house inscriptions. ${ }^{3}$ The use of stone in headstones is clearly related to its use in vernacular building and this suggests that headstones should rather be seen as a byproduct of stonecutters' activity. ${ }^{4}$ Stone was mainly worked for the production of columns, door and window jambs, or dimension stones, in other words the basic components needed for the construction of buildings. ${ }^{5}$

The absence of headstones in the major part of the Netherlands, in contrast to the regions to the south-east (characterised by the dense occurrence of cruciform headstones) and the north-west (mainly in the form of tablets and poles), has previously been noted in a study by Belonje. ${ }^{6}$ The author also referred to related monuments on the North-Frisian islands near Denmark (Figure 2), connecting these 'stone charters' more specifically to the history of Arctic whaling. Belonje supposed that in former times headstones existed in the intermediary area between the south-east and north-west of the Netherlands, yet did not study this matter in depth. ${ }^{7}$

\footnotetext{
${ }^{2}$ G. Franz, Der Dreissigjährige Krieg und das deutsche Volk, Stuttgart, 1979.

${ }^{3}$ H. Mytum, Remembering the dead on stone markers, British Archaeology 40 (1998) 6-7.

${ }^{4} \mathrm{~S}$. de Jonghe, H. Gehot, L. Genicot, P. Weber and F. Tourneur, Pierres à bâtir traditionnelles de la Wallonie, Manuel de terrain, Namur, 1996; W. Kasig, Zur Geologie des Aachener Unterkarbons (Linksrheinisches Schiefergebirge, Deutschland): Stratigraphie, sedimentologie und palaeogeographie des Aachener Kohlenkalks und seine Bedeutung für die Entwicklung der Kulturlandschaft im Aachener Raum, Aachen, 1980.

${ }^{5}$ de Jonghe, Gehot, Genicot, Weber and Tourneur, Pierres à bâtir traditionnelles de la Wallonie (note 4); Kasig, Zur Geologie des Aachener Unterkarbons (note 4); R. Dreesen, M. Dusar and F. Doperé, Atlas Natuursteen in Limburgse Monumenten, Hasselt, 2003; M. Dusar, R. Dreesen and A. De Naeyer, Renovatie en Restauratie - Natuursteen in Vlaanderen, Versteend Verleden, Dordrecht, 2009; A. Slinger, H. Janse and G. Berends, Natuursteen in Monumenten, Zeist/Baarn, 1980; R. Dreesen and M. Dusar, Historical building stones in the province of Limburg (NE Belgium): role of petrography in provenance and durability assessment, Materials Characterization 53 (2004) 273-287.

${ }^{6}$ J. Belonje, Steenen Charters (Oude Grafsteenen), Amsterdam, 1948.

${ }^{7}$ Belonje, Steenen Charters (note 6).
} 
In this paper, we seek to investigate the diffusion of seventeenth- and eighteenth-century headstones across the continental North Sea plain, particularly in relation to the evolution of Christianity in this region and to the supply of stone from the stony heights across long distances to places such as the Marsh Islands. Our study also aims to shed light on the degree to which the cross was accepted or rejected by various Christian faiths as a shape for headstones, a topic which has not received much attention. ${ }^{8}$ In contrast to earlier studies, the approach taken is supported by quantitative and cartographic methodologies. The empirical data for this research was gathered in fieldwork by the first author over the period between 1946 and 2009, as well as from existing surveys. ${ }^{9}$

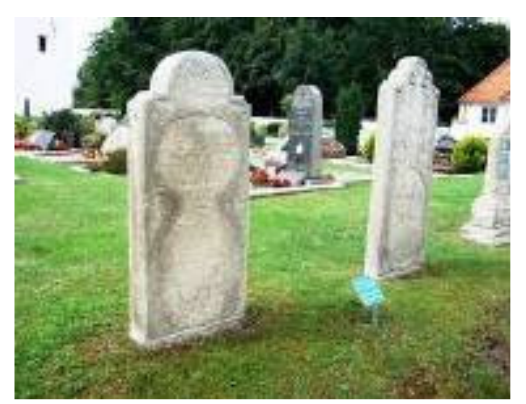

Figure 2. Headstones (seventeenth-century tablets) in Kirkeby on the Danish Marsh Island of Rømø (Photo: Jaak Nijssen, 2007).

\section{The study area: bio-physical and socio-historical contexts}

\footnotetext{
${ }^{8}$ M. Vogt-Lüerssen, Der Alltag im Mittelalter, 2006.

${ }^{9}$ K. Fischer, Die alten steinernen Grabkreuze im Kölner Raum - Eine Typenuntersuchung. (Diss. TH Darmstadt, 1956); W. Lüden, Redende Steine - Grabsteine auf der Insel Föhr, Hamburg, 1984; T. Möller, Der Kirchhof in Nebel auf Amrum und seine alten Grabsteine, Neumünster in Holstein, 1928; KIK-IRPA, Royal Institute for the Study and Conservation of Belgium's Artistic Heritage Photolibrary. http://www.kikirpa.be/www2/wwwopac/en/object.html, 2009; Türk, Christliche Kleindenkmale in Börde und Neffeltal, Habelt 1979; P. Bloys van Treslong Prins, J. Belonje and J. Westra van Holthe, Genealogische en Heraldische Gedenkwaardigheden in en uit de Kerken der Provincie [all Dutch provinces], Assen, 1919-1961; KNRM, Voorloopige Lijst der Nederlandsche Monumenten van Geschiedenis en Kunst, 1908-1933; C. Clasen, R. Wesenberg, A. Verbeek and H. Hilger, Die Denkmäler des Rheinlandes (Rheydt, Viersen, Kleve, Duisburg, Mönchengladbach, Oberbergischer Kreis, Krefeld, Dinslaken, Bergheim, Rheinisch-Bergischer Kreis, Mülheim an der Ruhr, Oberhausen), Düsseldorf, 1964 1975; M. Sabrowsky, Grabstelen und Grabplatten im Oldenburger Land aus dem 17. und 18. Jahrhundert - CDRom www.familienkunde-oldenburg.de, 2007; U. Siebert, Historische Grabsteine, Sammlung - Eine Foto- und Inschriftendokumentation historischer Grabsteine für den Raum Bremen. http://www.genealogy.net/vereine/maus/datenbanken/grabsteine/siebert.php 2005; J. T. Bremer, Oorkonden in Steen - 17e en 18 e eeuwse Grafzerken op de Oude Begraafplaats van Huisduinen / Den Helder, Schoorl, 1992; G. Quedens, Die alten Grabsteine auf dem Amrumer Friedhof, Amrum, 1984; D. Vermeulen, Grafschriften en Andere Genealogische en Heraldieke Merkwaardigheden in en om de Kerken

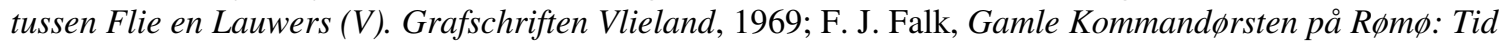
og Evighed; i Ord og Billeder, Rømø, 1988; K. Freckmann and H. Bölling, Alte Grabkreuze im Siebengebirge und an der unteren Sieg, Köln, 1983; R. Jeuckens, Die alten Steinkreuze im Aachener Grenzland, Aachen, 1938; W. Kaefer, Témoins muets du passé. Croix vicinales de la région de Malmedy. Étude d'épigraphie. 4. Commune de Bellevaux-Ligneuville, Malmédy-Folklore 39 (1975); H. Kandt, N. Göbel and E. Wolin, Steinerne Grabkreuze aus drei Jahrhunderten im Stadtgebiet Grevenbroich, Grevenbroich, 1980; A. Puters, Croix de pierre en Pays Mosan, Liège, 1957; J. Azzola and F. Azzola, Mittelalterliche Scheibenkreuz-Grabsteine in Hessen, Kassel, 1972; K. Müller-Veltin, Mittelrheinische Steinkreuze aus Basaltlava, Neuss, 1980; C. Kockerols and T. Dagnelie, Schiste, pierre d'Ardenne: croix funéraires, croix des chemins et autres monuments en Ardenne, Etalle, 1993.
} 
The continental North Sea plain $\left(1^{\circ} 30^{\prime}\right.$ to $10^{\circ} \mathrm{E} ; 50^{\circ}$ to $\left.56^{\circ} \mathrm{N}\right)$ is bordered in the southeast by the 'Mittelgebirge' of the Ardennes and Rhenish Massif and the Weserbergland which reach a height of $700 \mathrm{~m}$ above sea level in Belgium (Botrange) and $880 \mathrm{~m}$ in Germany (Grosser Feldberg). The study area covers the whole plain as well as the rocky heights that border it towards the south and south-east (Figure 3).

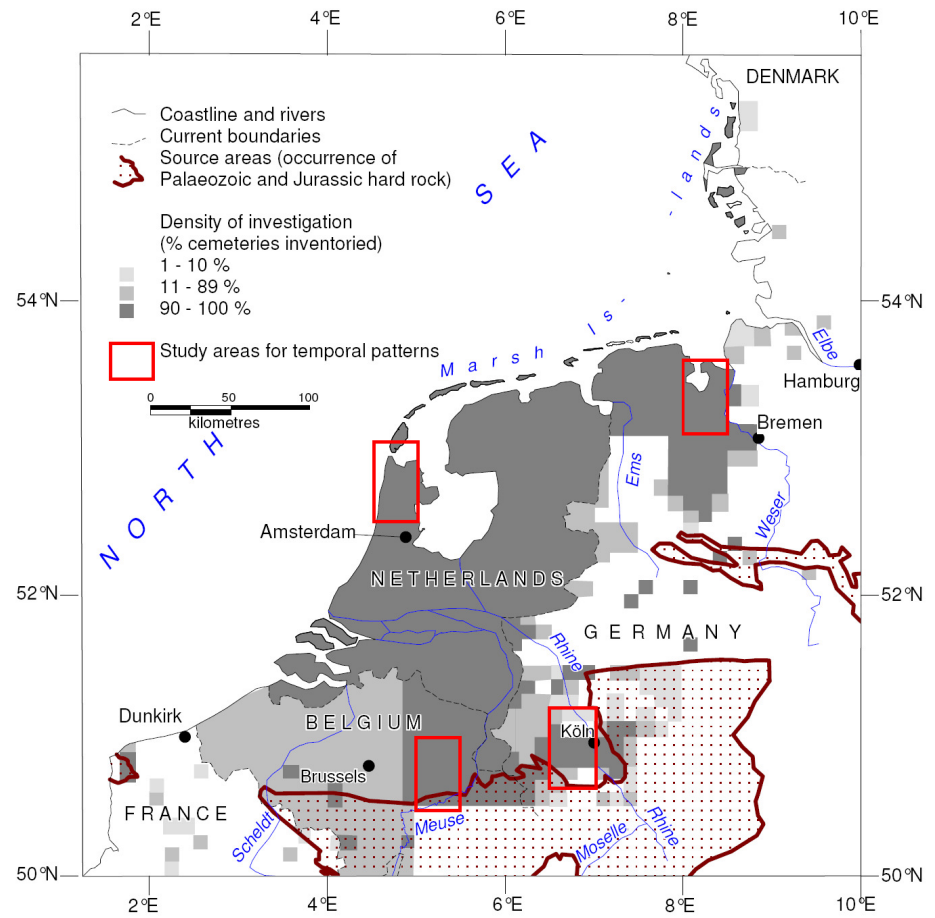

Figure 3. Study area (Mercator projection).

This shows the percentage of cemeteries that were investigated in each grid cell of 10' longitude by 6' latitude (approx. $120 \mathrm{~km}^{2}$ ). Blank areas were not investigated or not mentioned in any of the existing surveys. Source areas for the rocks used in headstone production are indicated. (The location of coastlines and rivers may vary).

\section{Aspects of demand: economy and society}

After 1600, the use of headstones became increasingly prevalent in the low countries. Headstones dating from before this period can be found only in the surroundings of Hainaut, Namur, Liège, Maastricht and Köln as well as the Thiérache. ${ }^{10}$ The subsequent expansion in the production and transport of headstones needs to be seen in the context of wider economic, political and social changes in the region as a whole during the seventeenth and eighteenth centuries. ${ }^{11}$ The period under study ends in 1800, as the preindustrial era itself is coming to a close. In the course of the nineteenth century, industry was to undergo revolutionary change in terms of both production and distribution. ${ }^{12}$

\footnotetext{
${ }^{10} \mathrm{~J}$. Nijssen, Vijf verwante gotische grafkruisjes, in De Band-Heem-Overmaas Jaarboek 49-59, 1971 ; J. Nijssen, Die Anfänge der steinernen Grabkreuze des Maaslandes, in: Internationale Tagung für Klein- und Flurdenkmalforschung (St. Magdalena, Linz, Austria, 28-31 May 1992), 1992; J. Timmers, De Kunst van het Maasland - Deel 2, De Gotiek en de Renaissance, Assen, 1980; Fischer, Die alten steinernen Grabkreuze im Kölner Raum (note 9).

${ }^{11}$ See below.

${ }^{12}$ Fischer, Die alten steinernen Grabkreuze im Kölner Raum (note 9).
} 
Providing a headstone for a deceased person depends on a certain level of prosperity, which in turn may be related to biophysical conditions, demography, and economic activity. ${ }^{13}$ The North Sea coastlands and the adjacent, generally narrow,strip of marshland were relatively fertile and therefore prosperous areas. In the Netherlands, the marshes were exceptionally wide, reaching up to a maximum of $90 \mathrm{~km}$. Further inland there was a poorer belt of moraines, riverine and/or aeolian sands, heaths, swamps, making up the largest portion of the North Sea plain. ${ }^{14}$ Further south lies another fertile belt, composed of aeolian silt (loess), roughly parallel to the limit of the Pleistocene glaciations, stretching from northern France through the central Belgian loess belt to Germany, where the narrower and rather discontinuous Börden are located. The southern part of this belt coincides with the northern edge of the rocky heights bordering the plain. At the longitude of the Rhine, this succession is interrupted by the $60 \mathrm{~km}$-wide Cologne Bight with loess soil, an especially mild climate and a southern border composed of volcanic rocks. The eastern part of the North Sea plain is bordered by the Teutoburger Wald.

Besides favourable soils, the fortunes of local agriculture depended on proximity to markets in large towns. During the sixteenth century, rates of urbanisation in the southwestern part of the study area - Bruges, Ghent, Brussels and Liège - were twice that found in the rest of the study area. ${ }^{15}$ Subsequently, during the eighteenth century, other cities, especially Amsterdam, experienced a demographic boom. ${ }^{16}$ Bremen started its boom at the beginning of the industrial revolution, reaching 35,000 inhabitants in $1815 .{ }^{17}$

North Sea whaling and seal hunting also had an important impact on the regional economy during the seventeenth and eighteenth centuries. ${ }^{18}$ Commercial and military navigation and shipbuilding were a significant basis for local wealth, generating a market for headstone supply. Ship owners from Hamburg and particularly from Amsterdam organised whaling and seal hunting, recruiting sailors as well as officers from the Marsh islands. 'Kapitänshäuser' in Vegesack (Bremen) and on the islands, as well as many headstones, were erected to memorialise the captains, who were often Mennonites. ${ }^{19}$ After 1700, Arctic whaling activities declined, due to the effects of overhunting. By 1800 just a handful of whale ships sailing under Hamburg or Bremen flags (though financially supported by Dutch entrepreneurs) worked the cold waters of Svalbard and the Davis Strait. ${ }^{20}$ More generally, the coastal settlements on the North Sea Plain provided access to the Arctic and Atlantic Oceans for a hinterland stretching to the Alps. The Dutch Republic in particular exploited its strategic location to become a civilian as well as a

\footnotetext{
${ }^{13}$ H. Mytum, Popular attitudes to memory, the body, and social identity: the rise of external commemoration in Britain, Ireland and New England, Post-Medieval Archaeology 40 (2006) 96-110; S. Tarlow, Bereavement and Commemoration: An Archaeology of Mortality, Oxford, 1999.

${ }^{14}$ Examples are the Houtland in France, the Kempen in Belgium, the Veluwe in the Netherlands as well as the Geest area and the Lüneburger Heide in Germany.

${ }^{15}$ E. Landsteiner, Mitteleuropa im 16. Jahrhundert, in E. Bruckmüller and P. Hartmann, eds., Putzger Historischer Weltatlas, 92, 2001.

${ }^{16}$ A. Maddison, The World Economy: A Millennial Perspective, Paris, 2006.

${ }^{17}$ H. L. Schaefer, Bremens Bevölkerung in der ersten Hälfte des neunzehnten Jahrhunderts, Veröffentlichungen aus dem Staatsarchiv der Freien Hansestadt Bremen 25 (1957) 35.

${ }^{18}$ Belonje, Steenen Charters (note 6).

${ }^{19}$ P. Alexander, The North-west and North-east passages 1576 - 1611, 1915; K. Lengsfeld, Der historische Walfang der Nordfriesen, 1991; J. Schokkenbroek, Trying-out: An Anatomy of Dutch Whaling and Sealing in the Nineteenth Century, 1815-1885, Amsterdam, 2008; C. van Bochove and J. Luiten van Zanden, Two engines of early modern economic growth? Herring fisheries and whaling during the Dutch Golden Age (1600-1800), in S. Cavaciocchi, ed., Ricchezza del Mare Secoli XIII-XVIII, 557-575 (Prato, Italy, 2006).

${ }^{20}$ Schokkenbroek, Trying-out (note 19).
} 
military maritime world power. In the Zaanstreek, the epicentre of shipbuilding in the Netherlands, hundreds of ocean-going vessels were built, on dozens of wharves, each year. ${ }^{21}$ During the period covered by this study, Antwerp was under Habsburg control and was separated from the sea by political borders. As European merchants were increasingly oriented to the Atlantic trade, Hamburg grew in importance and Bremen/ Vegesack started to be used as a harbour in $1620 .^{22}$

The marking of graves must be understood in the context of religious practice, which played a significant role in everyday life - and death. ${ }^{23}$ In the area and period under study, the only organised religions were Christianity and Judaism. Christians were inclined to exteriorize their confession by the use of crosses to mark graves. During the sixteenth and seventeenth centuries, especially, the study area was marked by the proliferation and differentiation of Christianity. Anabaptists (Mennonites), Reformed (Calvinists), Lutherans and (Catholic counter-reformist) Tridentines conquered and consolidated somewhat homogenous territories, respectively in the north, the northwest, the east and the south-east of the North Sea plain. Baptists demanded sobriety in marking graves, even prohibiting grave marking by headstones. ${ }^{24}$ On the other hand, the wish for commemoration and the value placed on status would also have led to increased demand for more substantial markers of graves. Ashkenazi Jews meanwhile preferred headstones as grave markers, while Sephardim preferred slabs (which are not considered in this study). ${ }^{25}$

\section{The supply of materials}

Stone was supplied to the low countries from the east-west stretching Hercynian Chain of the Rhenish-Eifel-Ardennes massif, which is interrupted by the Cologne Bight and limited in the east by the Weserbergland. ${ }^{26}$ The core of the massif consists of metamorphic rocks, mostly slate, with a rather poor value as construction material. ${ }^{27}$ This core is bordered to the north and the west by a fringe of mid-Devonian to late Carboniferous rocks, products of alternating sea transgressions and regressions during the first stages of the Hercynian orogenesis. At the southern edge of the massif, this fringe is less important (Limburg-an-der-Lahn). The fringe consists of limestone and sandstone, in intermittent crests and troughs, roughly stretching from east to west. The proto-Hercynian belt was the principal pre-industrial provider of stone for construction material and headstones for the plain. From west to east (Figure 3), it consists of (1) the 'Boutonnière du Boulonnais', an isolated geological feature, very restricted in area, with a Devonian and Carboniferous core; (2) in Hainaut, Devonian-Carboniferous limestone strata

\footnotetext{
${ }^{21}$ Schokkenbroek, Trying-out (note 19).

${ }^{22}$ W. Jochmann and H.-D. Loose, Hamburg : Geschichte der Stadt und ihrer Bewohner. Bd. 1. Von den Anfangen bis zur Reichsgrundung, Hamburg, 1982.; D. Steilen, Geschichte der bremischen Hafenstadt Vegesack, Bremen-Vegesack, 1926.

${ }^{23}$ P. Ariès, Images de l' homme devant la mort, Paris, 1983.

${ }^{24}$ M. Straatsma, De Amelander Walvisvaart, Ameland, 1984; R. Veit and M. Nonestied, New Jersey Cemeteries and Tombstones: History in the Landscape, 2008.

${ }^{25}$ J. Lokers, Die Juden in Emden 1530-1806, Aurich, 1990; Jewish Community of Middelburg (NL), Personal communication, 2009.

${ }^{26} \mathrm{P}$. de Béthune, Carte géologique de la Belgique et des régions voisines - 1:600 000, Louvain, 1958; $\mathrm{R}$. Walter, Geologie von Mitteleuropa, Stuttgart, 1992.

${ }^{27}$ de Jonghe, Gehot, Genicot, Weber and Tourneur, Pierres à bâtir traditionnelles de la Wallonie (note 4).
} 
outcropping in river incisions through the southern part of the post-Hercynian strata (quarries of the Tournaisis at Ecaussines); (3) north of the Sambre-Meuse-Vesdre string, a proto-Hercynian belt providing limestone, for example at Vinalmont; ${ }^{28}$ (4) from northwestern France to the south of Aachen (Germany), Devonian and Carboniferous strata alternating in the Avesnois and the Condroz (limestone and sandstone); (5) the Cologne Bight bordered at the south by Tertiary and Quaternary igneous rocks of Vulkaneifel and Siebengebirge, providing andesite, trachyte and basalt; (6) Triassic sandstone from the Weserbergland which was an extremely important material in the construction of both buildings and headstones.

Within the North Sea plain, isolated areas with sand concretions, whether calcareous or silcretic, sometimes provided a significant amount of building materials, such as the Balegem and Gobertange sandy limestones or the Bentheim sandstone, but these were of merely local interest in the production of headstones. ${ }^{29}$ Therefore, they will not be considered further in this study (Table 1).

Table 1. Post-Hercynian materials with only local significance for headstone production, in the continental North Sea plain

\begin{tabular}{|c|c|c|c|c|}
\hline Geological unit $^{1}$ & Lithology & Era & $\begin{array}{c}\text { Number of pre- } \\
\text { industrial head-stones } \\
\text { identified }^{2}\end{array}$ & Dates \\
\hline Balegem/Lede & Lime-sandstone & Eocene & Only building material & \\
\hline Gobertange & Sandy limestone & Eocene & 100 & $1600-1800$ \\
\hline Tienen & Quartzite & $\begin{array}{c}\text { Palaeocene- } \\
\text { Eocene }\end{array}$ & Only building material & \\
\hline $\begin{array}{l}\text { Maastricht } \\
\text { Valkenburg }\end{array}$ & Chalk & Cretaceous & 20 & \\
\hline Nievelstein & Sandstone & Pliocene & 100 & $1400-1800$ \\
\hline Liedberg & Sandstone & Miocene & 200 & $1700-1800$ \\
\hline Bentheim & Sandstone & Cretaceous & Only building material & \\
\hline
\end{tabular}

Unlike 'higher' stone work such as slabs, there is relatively little evidence available on the processes by which headstones were cut and shaped. ${ }^{30}$ In particular, it is unclear whether headstones were cut by a particular class of stonecutters. We assume that much of the processing of the stone took place in the quarry itself, since the mass of the stone was reduced to half when producing a tablet and to a third when producing a cross, representing a significant saving in potential transport costs. This does not include that

\footnotetext{
${ }^{28}$ The Mid-Devonian sandstone of this area has not been found in headstones : see de Jonghe et al., Pierres à bâtir traditionnelles de la Wallonie (note 4).

${ }^{29}$ Liedberg, Nievelstein and Tienen sandstones.

${ }^{30}$ D. J. Meer, Grafschriften en Andere Genealogische en Heraldieke Merkwaardigheden in en om de Kerken tussen Flie en Lauwers (IV). Grafschriften Menaldumadeel, 1950; L. Nys, La Pierre de Tournai. Son exploitation et son usage aux XIIIème, XIVème et XVème Siècles, Louvain-la-Neuve, 1993.
} 
part of the processing, especially the fine work, which was done closer to the final location of the monument, the village burial ground. ${ }^{31}$ One must also consider the possible influence of itinerant craftsmen. Moving or displaced stonecutters introduced new styles. For instance, some discoid crosses in the Pyrenees, in the North Sea plain and adjacent heights as well as in Kent so closely resemble each other that they may well have been the work of travelling craftsmen, reflecting common practices in mediaeval building yards. ${ }^{32}$

\section{$\underline{\text { Trade, politics and language }}$}

In the distribution of such a bulky product, navigable rivers played a major role. Due to their position between the heights and the sea, approximately ten rivers cross the eastwest geomorphological belts perpendicularly. This orientation contrasts sharply with the subsequent structural orientation of the central Meuse valley, in combination with its tributaries, the Sambre and the Vesdre. Their common valley is parallel to the Ardennes crest, and incises a major part of the proto-Hercynian fringe mentioned above. At the river mouths, the coastline was used for coastal navigation.

This river trade was seriously affected by political circumstances. Around 1500, a large part of the power over the study area was in the hands of the Habsburg dynasty, and so linked to the kingdom of Spain and Austria as well as to Catholicism. Large sovereign bishoprics (Liège, Köln, Münster, Bremen) as well as various smaller domains (Jülich, Eastern Frisia) made up the rest of the territory. The Treaty of Westphalia (1648) resulted in the secession of the Dutch Republic. Immediately, the Scheldt estuary was closed. The Dutch emerged as a maritime world power during their Golden Century; they had the largest mercantile fleet in Europe, ensuring a dominant position in European, especially Baltic, trade. Sephardic Jews, expelled from Portugal, contributed to the wealth of the new Republic and protestant areas like Middelburg, Amsterdam, Bremen or Hamburg, which welcomed them. Somewhat later, less wealthy Ashkenazi Jews came to these areas, after being expelled from eastern Germany. Jews had their own commercial circuits.

Following the coastline eastward, the East-Frisian princes held power, under the influence of Reformed and Mennonite Christianity. Further to the East, the confession was Lutheran in the Imperial Town of Bremen, the duchy of Bremen-Verden, the Imperial town of Hamburg, the Danish (but partly German-speaking) territories of Holstein and Slesvig and the Danish-linked county of Oldenburg. ${ }^{33}$ Along the Elbe River, Denmark had established the harbours of Altona and Glückstadt as rivals to Hamburg. Further inland, the bishoprics of Liège, Köln and Münster remained Catholic. The other major areas of stone supply remained Habsburgian and Catholic. The French annexed

\footnotetext{
${ }^{31}$ Lüden, Redende Steine (note 9); Möller, Der Kirchhof in Nebel auf Amrum (note 9).

${ }^{32}$ J. Nijssen, Fehlen Scheibenkreuze sowie Rad- und Ringkreuze zwischen Ems und Seine?, Journées de Carcassonne: signalisations de sépultures et stèles discö̈dales V-XIX Siècles 13-29; 220-221 (1990); J. Nijssen, Les discoïdales et leurs alternatives dans le nord-ouest du continent, Hil Harriak (Bayonne) (1984) 347-360; J. Nijssen, Un monumento casi-discoideo en Mastrique (Maastricht), Países Bajos, Cuadernos de Etnología y Etnografía de Navarra 66 (1995) 315-326; P. Ucla, Atlas des stèles discoüdales, Paris, 1990.

${ }^{33}$ Because of its neutrality, Oldenburg remained immune from the terrible devastations to which nearly all the other states of Germany were exposed during the Thirty Years' War: see Franz, Der Dreissigjährige Krieg und das deutsche Volk (note 2).
} 
parts of the Habsburgian Low Countries, especially during the reign of Louis XIV. An example of direct political intervention in commercial matters is the ban on the import of stone by Louis XV of France. Throughout the period under study, tolls continued to restrict trade. By the end of the eighteenth century, the map of the whole region had been transformed by the effects and consequences of the French revolution..

Interregional trade does not seem to have been significantly hampered by linguistic differences, of which there were many. The more prosperous western part of the stoneproviding areas were dominated by Roman language speakers (Walloon and French) living under Habsburgian, Catholic episcopal rule, while a large part of their customers in the downstream areas were Low German speakers who converted into Calvinism in the Republic. $^{34}$ Ashkenazi Jews, meanwhile, mainly spoke Yiddish, though their official language was Hebrew. The tiny population on the Marsh Islands used the Frisian language. Headstones provide rich evidence of these linguistic circumstances. For example, headstones with inscriptions in two or three different languages coexist in the same cemetery. ${ }^{35}$ It is worth mentioning that an analysis of epigraphy on these thousands of gravestones would yield important information on the spatio-temporal evolution of language forms in this region where different cultures were in such close contact.

As grave crosses were used as a means of displaying religious conviction, if not proselytism, they could also be targeted and destroyed in periods of religious conflict. Such was the case with the iconoclasm of the Reformation in 1566 in the western part of the North Sea plain and also during the French revolution, when much religious imagery was destroyed. In 1804, Napoleon forbade cemeteries within town walls and many of them were destroyed. ${ }^{36}$ In the course of the twentieth century, there were major destructions of Jewish headstones during the Holocaust period (1933-1945), as well as destruction caused by the effects of the two World Wars, poorly conceived (urban) planning or simply negligence. ${ }^{37}$ We consider destruction due to negligence as a random factor inasmuch as these destructions will not have affected the overall spatial distribution of headstones in the study area. On the other hand, increasing awareness regarding the value of small monuments has also led to the recovery of many of them from the forgotten corners of local cemeteries.

\section{Research methodology}

This study considers the geographical locations of headstones, the materials used to construct them, and the variation in their design (Figure 1). In some regions, especially western Hainaut, the Avesnois and the region around Antwerp, upstanding slabs and epitaphs embedded in church walls were used in place of headstones. ${ }^{38}$ Neither these constructions nor footstones are included here. In line with our focus on headstones, we

\footnotetext{
${ }^{34}$ During the period of this study, the Dutch language continued to develop across the region that is now Belgium and the Netherlands. In northern Germany, the Low German was gradually replaced by the High German, particularly under the influence of Luther's High German translation of the Bible.

${ }^{35}$ J. Nijssen, Oude stenen graf- en veldkruisen, Ons Heem 15 (1960) 41-48.

${ }^{36}$ P. Moreaux, Quelques aspects de l'histoire funéraire dans la civilisation judéo-chrétienne en France, Etudes sur la mort 125 (2004) 9-21.

${ }^{37}$ Lokers, Die Juden in Emden (note 25); Joods Historisch Museum, Amsterdam. http://www.jhm.nl/, 2009

${ }^{38}$ Author's observations; KIK-IRPA (note 9).
} 
have also excluded the few surviving grave markers constructed in whale jawbone, in wood, or in cast or forged iron. ${ }^{39}$

\section{$\underline{\text { Fieldwork and sources }}$}

Between 1946 and 2009, the first author conducted extensive fieldwork in the study area, documenting around 6,000 headstones in approximately 1,000 cemeteries, using standard procedures. $^{40}$ The area between $5^{\circ}-6^{\circ} 30^{\prime} \mathrm{E}$ and $50^{\circ} 30^{\prime}-51^{\circ} 30^{\prime} \mathrm{N}$ was exhaustively

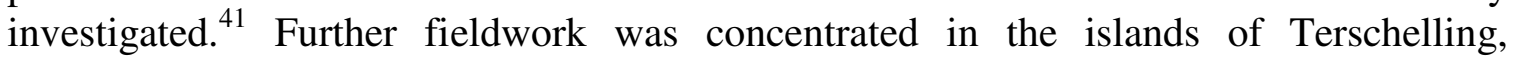
Vlieland, Texel, Rømø, Nordstrand, Amrum, Pellworm and Föhr, as well as the Alkmaar, Middelburg, Boulonnais, Wesermarsch and Oldenburg regions. All these headstones were recorded in a database.

An investigation such as this, concerned with the presence or absence of particular kinds of grave marker, necessarily raises questions about interpretation. For example, does the absence of evidence really mean that there are areas where certain kinds of headstone were never used, or do they suggest incomplete investigation? For this reason, selected areas without reported headstones, particularly in northern France as well as between Rhine and Weser in Germany, were exhaustively re-visited (all the cemeteries in clusters of a dozen of villages for every sample). This allowed confirmation of the absence of headstones or (in a few cases) correction of the original data. Additional observations with the same aim in mind were made along randomly spread transects of cemeteries.

Archival research yielded some information on events leading to the erection of a few headstones but was less useful in interpreting overall patterns of distribution. Over the course of several decades, the first author, a local history researcher, scoured hundreds of archives, finding only a few mentions of the erection or presence of headstones. Neither did they offer significant additional information, which might have complemented in situ observations on graveyards.

For parts of our study area, surveys of headstones have already been published. However, they vary in quality and utility. The inventories done in the Netherlands in the first half of the twentieth century neglected objects which did not bear an inscription, as those are less interesting for genealogists, and did not include any information about the source material. ${ }^{42}$ However, a comparable edition, this time including such details, is available for parts of the German Land Nordrhein-Westfalen. ${ }^{43}$ The former Grand Duchy of Oldenburg has also been treated exhaustively, as well as Land Bremen. ${ }^{44}$ Belgium,

\footnotetext{
${ }^{39}$ Belonje, Steenen Charters (note 6); A. Van Deinse, De Walvischachtige Dieren van Nederland. Fossiele Zoowel als Recente, Paris, Amsterdam, 1931; H. de Walle, Friezen uit Vroeger Eeuwen: Opschriften uit Friesland, 1280-1811, 2007; H. Hilger, Die Denkmäler des Rheinlandes. Kreis Kleve 4, Düsseldorf, 1967; B. C. Zeguers, Kruisen in Limburg, Rotterdam, 1972; Türk, Christliche Kleindenkmale in Börde und Neffeltal (note 9); W. F. Van Heemskerk-Düker and H. J. van Houten, Zinnebeelden van Nederland, Amsterdam, 1941; D. Van Loo, Van grafstenen en begraafplaatsen, Hamer 1 (1941) 11.

${ }^{40}$ F. J. Baker, D. Farber and A. G. Giesecke, Recording cemetery data, Markers I (1980) 98-117.

${ }^{41}$ This corresponds to the region between the towns of Namur, Malmédy, Xanten and 's Hertogenbosch.

${ }^{42}$ Bloys et al., Genealogische en heraldische gedenkwaardigheden (note 9); KNRM, Voorloopige Lijst (note 9).

${ }^{43}$ Clasen et al., Die Denkmäler des Rheinlandes (note 9).

${ }^{44}$ Sabrowsky, Grabstelen und Grabplatten im Oldenburger Land (note 9); Siebert, Historische Grabsteine (note 9).
} 
meanwhile, is documented by a valuable collection of photographs of monuments, including 4,169 headstones. ${ }^{45}$ In addition, the well-documented case studies of the Marsh Islands and of the wider Köln-Aachen area have considerable value for the purposes of this study. ${ }^{46}$

While some geneaologists have undertaken comprehensive surveys of headstones in some areas, they seldom specify the materials used. ${ }^{47}$ Other authors confine themselves to some specific aspect of the headstones such as discoidal shape, or to lithology, thus limiting their usefulness for this study. ${ }^{48}$ Furthermore, the focus of previous studies is on existing headstones: there are no studies which consider the absence of headstones in particular areas. Who has ever seen a publication entitled 'The nonexistent headstones of $\mathrm{X}^{\prime}$ ? It is only possible to evaluate the significance of presence or absence in regionallevel surveys of the distribution of monuments, provided that these are detailed to the level of individual headstones.

\section{$\underline{\text { Database management and spatial analysis }}$}

All the data collected for this study (8,993 headstones in 3,299 settlements) were stored in a database (Filemaker Pro 7) and manipulated in Excel, for instance for the purpose of calculating densities and the analysis of temporal patterns. ${ }^{49}$

In order to detect configurations in the distribution of headstones, the spatial variability of their density was analysed. This analysis involved a certain simplification, as for this purpose the chronology was neglected (but see also the discussion of chronology below). Approximately 25,000 cemeteries (estimated by extrapolation) were grouped by grid cells, spherical rectangular tetragons with a latitude of 6' by a longitude of 10'. This unit of investigation appears as a square on maps using the Mercator projection (which is justified as the study area is sub-continental). ${ }^{50}$

While it was not possible to visit every cemetery in every individual grid cell, around half of the cells were exhaustively investigated, and sampling at different densities was done on the remainder (Figure 3 ). ${ }^{51}$ The headstone density per grid cell was then calculated. ${ }^{52}$

\footnotetext{
${ }^{45}$ KIK-IRPA (note 9).

${ }^{46}$ Lüden, Redende Steine (note 9); Möller, Der Kirchhof in Nebel auf Amrum (note 9); Bremer, Oorkonden in Steen (note 9); Quedens, Die alten Grabsteine auf dem Amrumer Friedhof (note 9); Vermeulen,

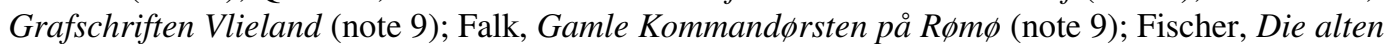
steinernen Grabkreuze im Kölner Raum (note 9); Türk, Christliche Kleindenkmale in Börde und Neffeltal (note 9); Freckmann and Bölling, Alte Grabkreuze im Siebengebirge (note 9); Jeuckens, Die alten Steinkreuze im Aachener Grenzland (note 9); Kaefer, Témoins muets du Passé (note 9); Kandt et al., Steinerne Grabkreuze aus drei Jahrhunderten (note 9); Puters, Croix de pierre en Pays Mosan (note 9).

${ }^{47}$ Including Jewish genealogists: Joods Historisch Museum (note 37).

${ }^{48}$ Ucla, Atlas des stèles discö̈dales; Azzola and Azzola, Mittelalterliche Scheibenkreuz-Grabsteine in Hessen (note 9); Müller-Veltin, Mittelrheinische Steinkreuze aus Basaltlava (note 9); Kockerols and Dagnelie, Schiste, pierre d'Ardenne (note 9).

${ }^{49}$ J. Nijssen, Maasländische Kleindenkmäler zu Internetzeiten, in: Arbeitstreffen der AGD Arbeitsgemeinschaft Denkmalforschung in Niedersachsen (Elze (D), 21 September 1996), 1996.

${ }^{50}$ The area of the different cells varies with latitude but is approximately $120 \mathrm{~km}^{2}$. All headstones on the cemeteries of a grid cell were considered as concentrated in its centre (rastering).

${ }^{51}$ We introduced four classes: first, grid cells that are exhaustively known (90\% at least, mostly $100 \%$ ). The second class consists of cells which we know for 11 to $89 \%$, whereas the third class includes cells of
} 
In the existing surveys, the absence of headstones is seldom considered explicitly. For the grid cells in which more than $10 \%$ of the cemeteries were investigated, the sample proved to be large enough so that 'zero headstones' really means that headstones are absent. Those grid cells where less than $10 \%$ of the graveyards were investigated were not taken into account for quantifying the negatives. While tallying headstones, we considered both those that are accessible today, as well as those recorded in earlier surveys, some of which may have disappeared. Once the densities per (investigated) grid cell were obtained, regional density maps were established through quadratic interpolation in MapInfo $^{\circledR}$ GIS software. Jewish headstones were additionally mapped in cells that were otherwise void of headstones.

Table 2. Characteristics of rectangles in which the temporal pattern of headstone construction was analysed (see also Fig. 3)

\begin{tabular}{llcccc}
\hline Central town & $\begin{array}{c}\text { Land area } \\
\left(\mathrm{km}^{2}\right)\end{array}$ & $\begin{array}{c}\text { Longitude } \\
\left({ }^{\circ} \mathrm{E}\right)\end{array}$ & Latitude $\left({ }^{\circ} \mathrm{N}\right)$ & $\begin{array}{c}\text { Number of dated } \\
\text { headstones }\end{array}$ \\
\hline SW & Sint-Truiden & 2390 & $5^{\circ}-5^{\circ} 30^{\prime}$ & $50^{\circ} 30^{\prime}-51^{\circ}$ & 452 \\
SE & Euskirchen & 2371 & $6^{\circ} 30^{\prime}-7^{\circ}$ & $50^{\circ} 30^{\prime}-51^{\circ}$ & 534 \\
$\mathrm{NW}$ & Alkmaar & 1326 & $4^{\circ} 30^{\prime}-5^{\circ}$ & $52^{\circ} 30^{\prime}-53^{\circ}$ & 111 \\
$\mathrm{NE}$ & Oldenburg & 1531 & $8^{\circ}-8^{\circ} 30^{\prime}$ & $53^{\circ}-53^{\circ} 30^{\prime}$ & 181 \\
\hline
\end{tabular}

As stated above, while many existing headstone inventories are quite detailed in recording shape and especially epigraphy, most do not mention lithology. Similarly, lithology was not accounted for in the first decades of the first author's field observations on headstones (1946-1985). We have based this part of the study on absolute numbers of headstones for which the lithology was recorded; observations on lithology are too fragmentary to calculate exact densities for wider regions. These observations enabled the preparation of distribution maps that use an ordinal scale including low, medium and high densities.

Timelines were drawn for selected parts of the study area. We chose four areas of $0.5^{\circ}$ longitude by $0.5^{\circ}$ latitude, which were thoroughly investigated with regard to number and date of headstones. These rectangles are centred on the towns of Sint-Truiden, Euskirchen, Alkmaar and Oldenburg (Figure 3) and each contain 15 grid cells (Table 2). To analyse trends in headstone establishment per rectangle, all dated headstones were grouped per decade and trend lines were established on the chronological pattern of the number of erected headstones.

which our knowledge is (very) limited. Finally, the fourth class contains the cells about which we have no information (Figure 3).

${ }^{52}$ Headstone density per grid cell was expressed as $\mathrm{D}=\mathrm{n} /(\mathrm{A} * \mathrm{i} * 1)$, where: $\mathrm{D}=$ density of headstones pertaining to the study period $\left(\mathrm{km}^{-2}\right), \mathrm{n}=$ absolute number of headstones counted on the surveyed cemeteries within the grid cell, $\mathrm{A}=$ area of the cell $\left(\mathrm{km}^{2}\right), \mathrm{i}=$ fraction of cemeteries investigated (dimensionless), and $\mathrm{l}=$ fraction of land within the cell (dimensionless). 


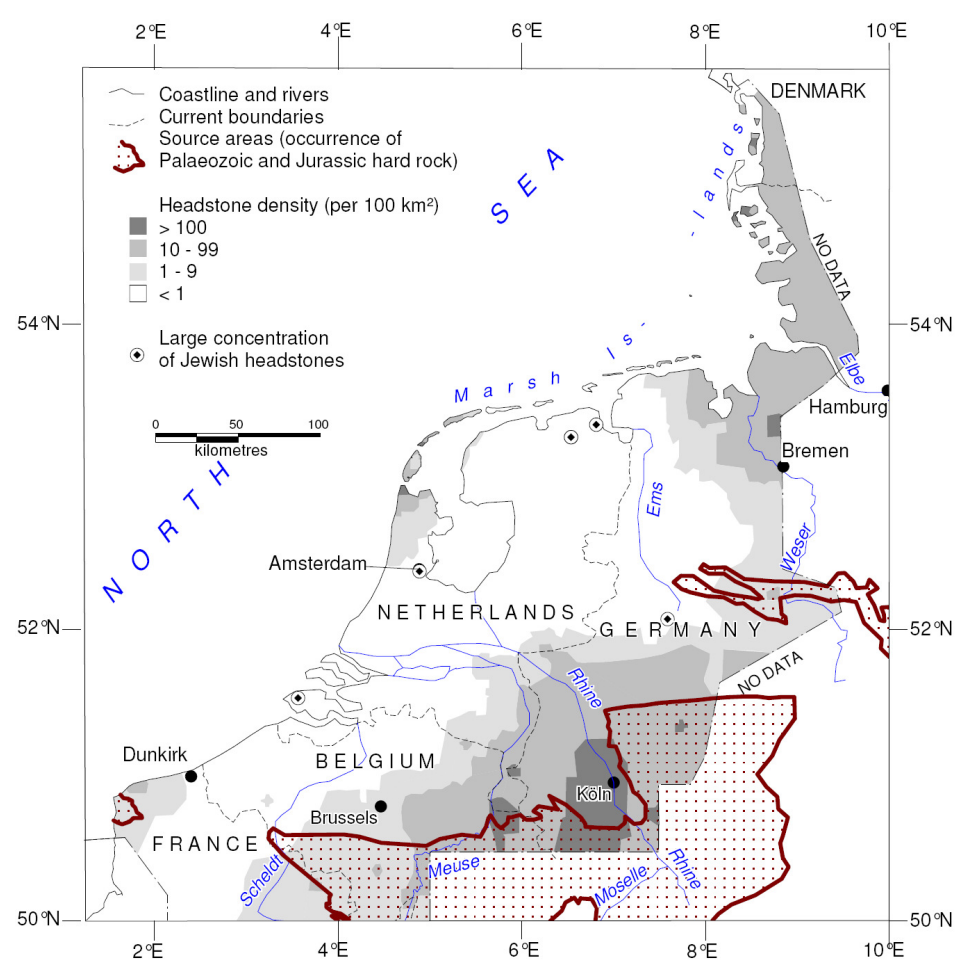

Figure 4. Density of seventeenth- eighteenth-century headstones in continental north-western Europe.

The figure is based on observations represented in Figure 3 and calculated using quadratic interpolation. The interpolation also includes the small intermediate areas that were not investigated. Note the logarithmic interval between the isolines. The major geographical patterns are (1) high density near the source areas (generally Hercynian mountain chains), (2) a belt stretching from northern France to northern Germany that contains few headstones (with the notable exception of some Jewish cemeteries, which are only denoted in those areas which otherwise do not contain headstones), (3) bulges in the belts where headstones have been transported from the source areas along major rivers (Meuse, Rhine and Weser) and (4) high density in the western and northern Marsh Islands. (The location of coastlines and rivers may vary).

\section{The spatial distribution of headstones}

The headstone distribution map (Figure 4) shows very strong gradients in density; therefore a logarithmic rather than a linear scale needed to be used when establishing the equidistance between isolines. Especially noteworthy are high densities ( $>1$ headstone per $\mathrm{km}^{2}$ ) in the stony uplands, as well as on the western and northern Marsh Islands.

The larger part of the production was for local customers, as indicated by the high densities in the Boulonnais and in most of the Ardennes-Rhenish massif (Figure 4). The central Ardennes were unproductive in sandstone grave crosses, yet had a high production of crosses in schist; the Eifel highlands produced a large number of Buntsandstein headstones, which were however only used locally. ${ }^{53}$

Two cases illustrate the intimate relation between quarry, stone carver and headstones. First, in an area of about $200 \mathrm{~km}^{2}$ between Liège, Maastricht and Aachen, a set of 51 gothic crosses is present, very similar in design (Figure 5). They are in flamboyant gothic style; if it is present, the corpus is the principal motif on the crosses, some of which also

\footnotetext{
${ }^{53}$ Kockerols and Dagnelie, Schiste, pierre d'Ardenne (note 9).
} 
have a short gothic inscription. ${ }^{54}$ They are all undated, but were probably erected between 1601 and $1610 .{ }^{55}$ Most typically, all these crosses were made of Carboniferous sandstone, the only known local quarry site of which is located along the Berwinne river near the Val-Dieu abbey (Aubel) at the centre of the cluster of crosses (Figure 6). ${ }^{56}$

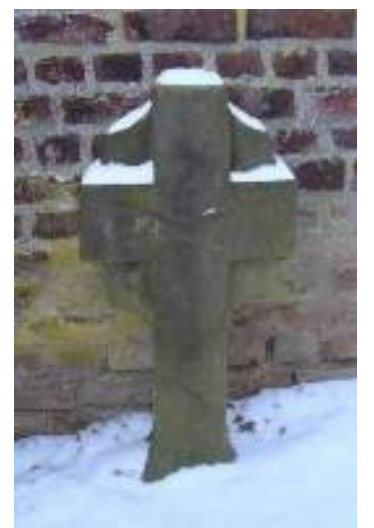

Figure 5. Gothic headstone, made of Carboniferous sandstone, at Julémont cemetery (Photo: Jan Nyssen, 2009).

In a second case, to the east of the previous example, 31 grave crosses in Palaeozoic limestone have been produced by another workshop which was particularly active between 1630 and 1640. Major outcrops of this lithology are located nearby, on the north flank of the Vesdre valley (Figure 6). They bear a crucifix with a typical corpus having a head strongly bent towards the right shoulder, lengthy thorns on the crown and long, mostly bent arms. Minor additional symbolism and sometimes heraldic elements are used. Remarkably, one of the crosses produced in this workshop that stands in the field near Grand-Rechain was actually erected in memory of a stone carver, most probably employed in the workshop. ${ }^{57}$ It bears the following inscription in a mix of French and Walloon languages:

\author{
PRIEZ DIEV \\ POVR L'ÂME D ' HONNEST \\ IEVNE HOME FRANÇOY FILS \\ DE SYER D' GRA TAILLEVR \\ D 'PIRRE QVI ES MORT D' \\ OCCISION LE \\ 9 FEB 1648
}
Pray God
for the soul of the honest
young man François son
of a nobleman from Gra[nd-Rechain] stone
carver who died
by murder on

\footnotetext{
${ }^{54}$ J. Nijssen, Fasen und Nasen an alten steinernen Kreuzen im Lande an der Maas - Beitrag zum Arbeitstreffen der AGD Arbeitsgemeinschaft Denkmalforschung (Tepla (CZ) 30 April - 3 May 1998) 1998.

${ }^{55}$ KIK-IRPA (note 9).

${ }^{56}$ R. Dreesen, Personal communication, Mol (B.), 2003.

${ }^{57}$ C. Bury, Le coin des chercheurs: Croix d'occis, Bulletin du Vieux-Liège 163 (1968) 343-344.
} 
Might his workshop have been located in or near one of the quarries of Palaeozoic limestone nearby the village of Grand-Rechain? Whatever might have been the case, only one more cross was produced in this workshop after 1648 (in 1655).

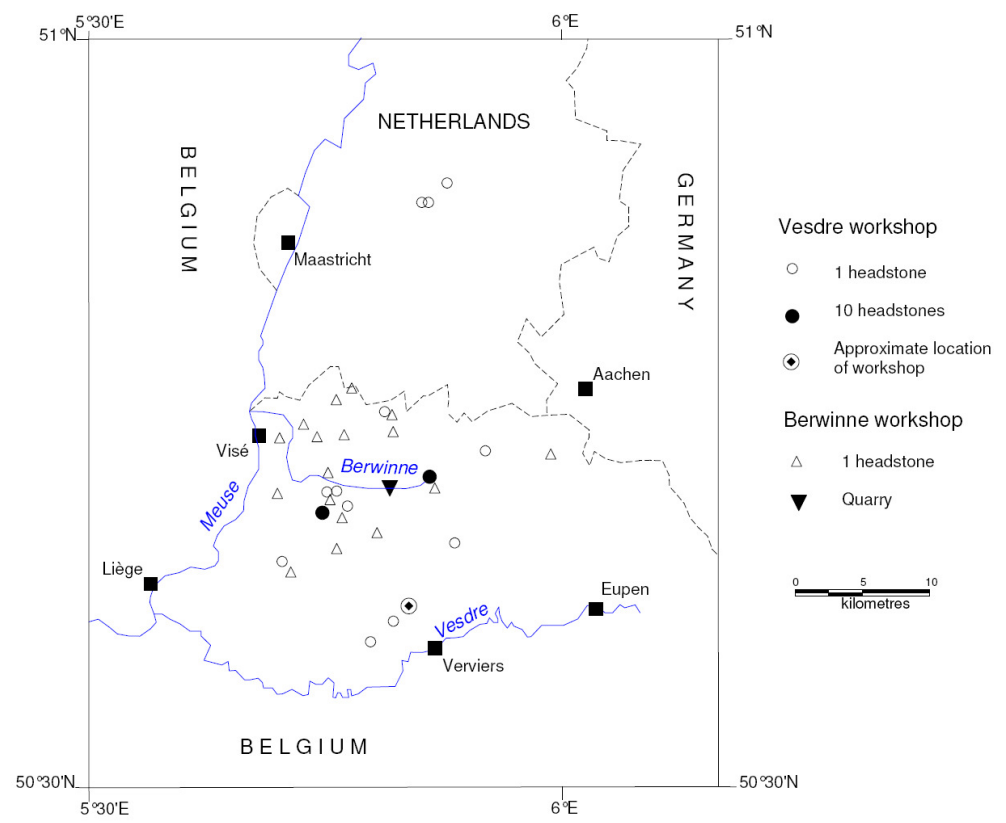

Figure 6. Distribution of the headstones produced in seventeenth-century workshops at Berwinne (Carboniferous sandstone) and Vesdre (Palaeozoic limestone).

\section{Across the continental North Sea plain}

A widespread and dense group of headstones in Palaeozoic limestone extends throughout the broader Meuse valley over a length of $250 \mathrm{~km}$ with a maximal width of $150 \mathrm{~km}$. The headstones are cross-shaped and the epigraphy shows remarkably little relief (in comparison to neighbouring groups). ${ }^{58}$ This group of headstones occurs near to the Meuse River, both where it incises the northern fringe of the Ardennes massif (with numerous quarries) and northward along the Meuse valley well into the Tertiary and Quaternary terrains without hard rock of the Netherlands (Figure 7). ${ }^{59}$

\footnotetext{
${ }^{58}$ Nijssen, Journées de Carcassonne (note 32).

${ }^{59}$ Headstones in Palaeozoic limestone occur for instance at 's-Hertogenbosch, Zaltbommel and Zutphen (Figure 7).
} 


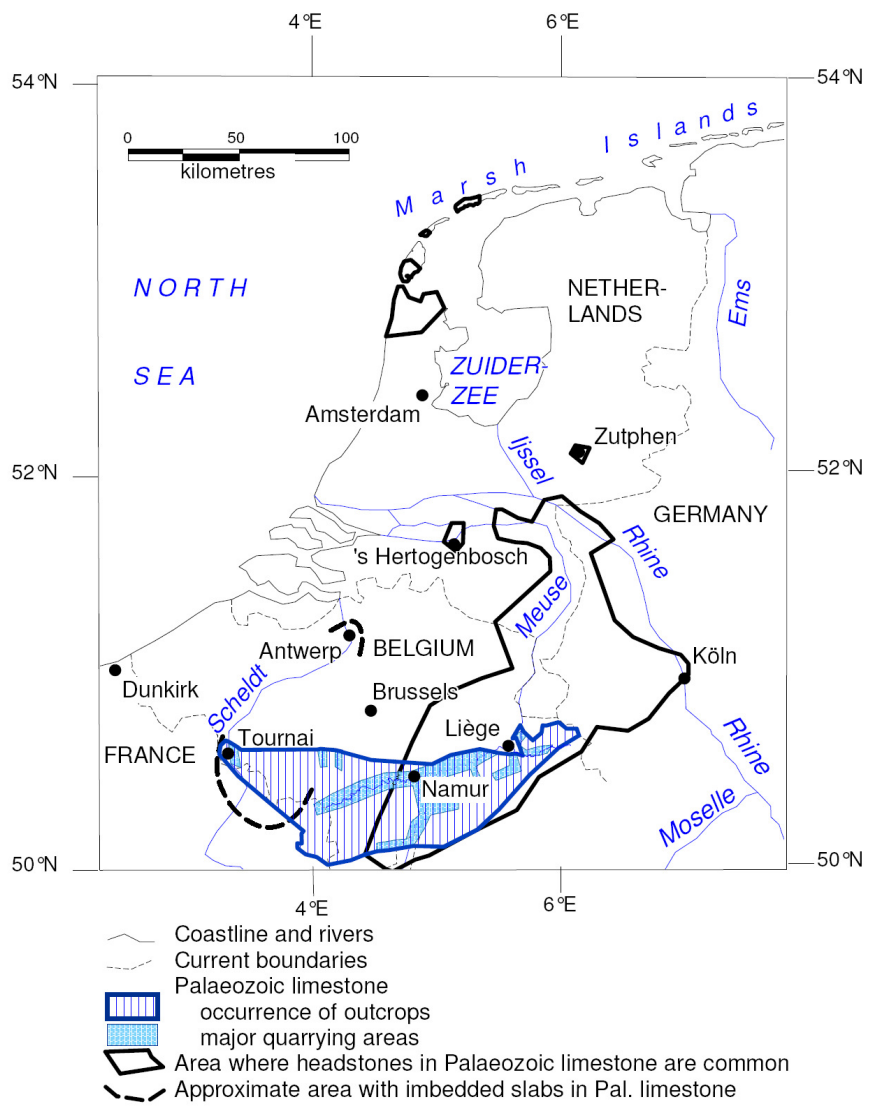

Figure 7. Occurrence of Palaeozoic limestone at the southern rim of the continental North Sea plain and areas where the same material was widely used for headstones.

The Meuse can be observed winding through the outcrops, and further north it served as a transport route, causing a bulge in the isolines of headstone distribution, away from the source area. The hypothetical route to North Holland and the Marsh Islands was through the River Ijssel and the Zuiderzee. The area where Palaeozoic limestone was used for embedded slabs of the same age is tentatively indicated by a dashed line.

In contrast, old steles are rare in the west of Belgium and the centre and north of the Netherlands. The only exception is the rich collection of steles in the extreme north-west of the Netherlands (Figure 4). On the churchyard of Huisduinen there are more than a hundred steles from the seventeenth and eighteenth century. Similar monuments are conserved on other churchyards in the neighbourhood, including the western Marsh Islands (Figure 8) albeit in smaller numbers. The inscriptions clearly suggest that the burials are mostly of people linked with the Amsterdam sea navigation, in particular with whaling. They include members of the Dutch Reformed Church, Anabaptists and Catholics.

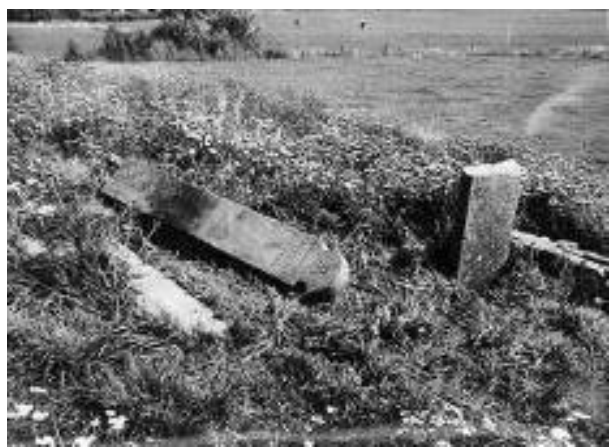

Figure 8. Poles at the Strijperkerkhof in Terschelling (Dutch Marsh Islands) in 1971 (Photo: Jaak Nijssen). The cemetery and headstones have been restored in recent years. 
The region without headstones extends from the central and northern Netherlands towards Münster in the East. At the edge of this region, Hilger's Kleve mentions the presence of headstones in only 4 of the 60 settlements covered in his study. ${ }^{60}$ To the South, the region extends to the whole centre and west of the Netherlands to include both Belgian Flanders and, surprisingly, the western Hainaut stone-producing area. In this area, particularly in the Reformed Netherlands, there exist a few cemeteries with Jewish headstones in regions which lack other headstones. Finally, to the extreme north of the study area, namely on the German and Danish Marsh Islands, there is an area with a higher density of headstones.

\section{$\underline{\text { Transfers after construction }}$}

Some headstones were moved, sometimes long after their erection. In many cases, headstones aligned against church walls were moved over short distances, as were headstone fragments sealed in the walls of churches and adjacent buildings. Some headstones were also found to be reused 50 or 100 years later, in which case either the old inscriptions had been ground off or the back was used (such as at Huisduinen and Helmond). At Xhoffraix (East Belgium), headstones that were removed during the French Revolution were re-erected along roads. Some headstones may have been moved over greater distances, which interfered with our analysis of spatial distribution. Six headstones, present in an otherwise 'vacuum' area at the St. Lucas Institute in Ghent were originally erected at Aubel, some $160 \mathrm{~km}$ to the east. ${ }^{61}$ In this case, and in a few others where the original location could be retraced, the headstones have been accounted for within their original location.

\section{Chronological patterns}

In the southern parts of the study area (Sint-Truiden, Euskirchen), headstone production was already important in 1600, with around 25 headstones per decade that have survived until today. The production of headstones soared in the early seventeenth century, especially in the area of Sint-Truiden. The number of established headstones is considerably lower and started later in the northern regions than in the southern regions, where there is also a time lag from west to east (Figure 9).

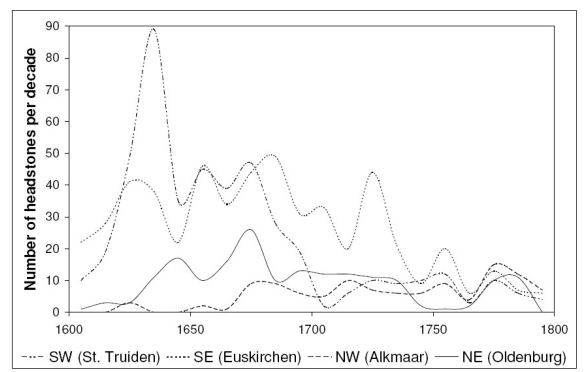

Figure 9. Number of headstones per decade in four selected areas of approximately the same size. The graph shows that in the southern regions, near the source areas, there is a larger number of headstones; and also that these clearly peaked in the seventeenth century, as opposed to the north-western Alkmaar region which experienced a gradual increase in number of headstones throughout the seventeenth and eighteenth centuries.

${ }^{60}$ Hilger, Die Denkmäler des Rheinlandes (note 39).

${ }^{61}$ Own observation. 


\section{$\underline{\text { Source materials }}$}

Evidence concerning the lithology of stones was retrieved for 2,945 headstones and then mapped (Figure 10). Out of these, there are 1,472 headstones in Palaeozoic limestone, 556 in various sandstones, 791 in volcanic rock and 126 in other rocks. Very high densities of headstones in Palaeozoic limestone, and very low densities of other lithologies, occur at the margin of the protohercynian fringe: for example, 121 in the grid cell around Visé, 101 around Sint-Truiden, and 120 around Aubel. ${ }^{62}$ In this latter area, the cemetery of Hombourg is the hotspot of seventeenth-century limestone grave crosses. Furthermore, the north-western Netherlands are outstanding for headstones in Palaeozoic limestone, particularly the cemetery of Huisduinen.

The highest densities of sandstone crosses can be found in the Siebengebirge: 104 in the Bergisches Land and 48 in Altenberg. ${ }^{63}$ Headstones in volcanic rock occur in the contact area between Eifel and Cologne Bight: 82 around Bonn and 115 in the grid cell around Brühl. ${ }^{64}$ Other lithologies mainly comprise schist, which appears particularly in grave markers in the Ardennes. ${ }^{65}$

\footnotetext{
${ }^{62}$ Centres of grid cells: Visé $\left(50^{\circ} 45^{\prime} \mathrm{N}, 5^{\circ} 45^{\prime} \mathrm{E}\right)$, Sint-Truiden $\left(50^{\circ} 15^{\prime} \mathrm{N}, 5^{\circ} 45^{\prime} \mathrm{E}\right)$, Aubel $\left(50^{\circ} 45^{\prime} \mathrm{N}\right.$, $\left.5^{\circ} 55^{\prime} \mathrm{E}\right)$.

${ }^{63}$ Centres of grid cells: Bergisches Land ( $\left.51^{\circ} 03^{\prime} \mathrm{N}, 7^{\circ} 15^{\prime} \mathrm{E}\right)$, Altenberg $\left(51^{\circ} 03^{\prime} \mathrm{N}, 7^{\circ} 05^{\prime} \mathrm{E}\right)$.

${ }^{64}$ Centres of grid cells: Bonn $\left(50^{\circ} 45^{\prime} \mathrm{N}, 7^{\circ} 05^{\prime} \mathrm{E}\right)$, Brühl $\left(50^{\circ} 48^{\prime} \mathrm{N}, 6^{\circ} 55^{\prime} \mathrm{E}\right)$.

${ }^{65}$ Kockerols and Dagnelie, Schiste, pierre d'Ardenne (note 9).
} 


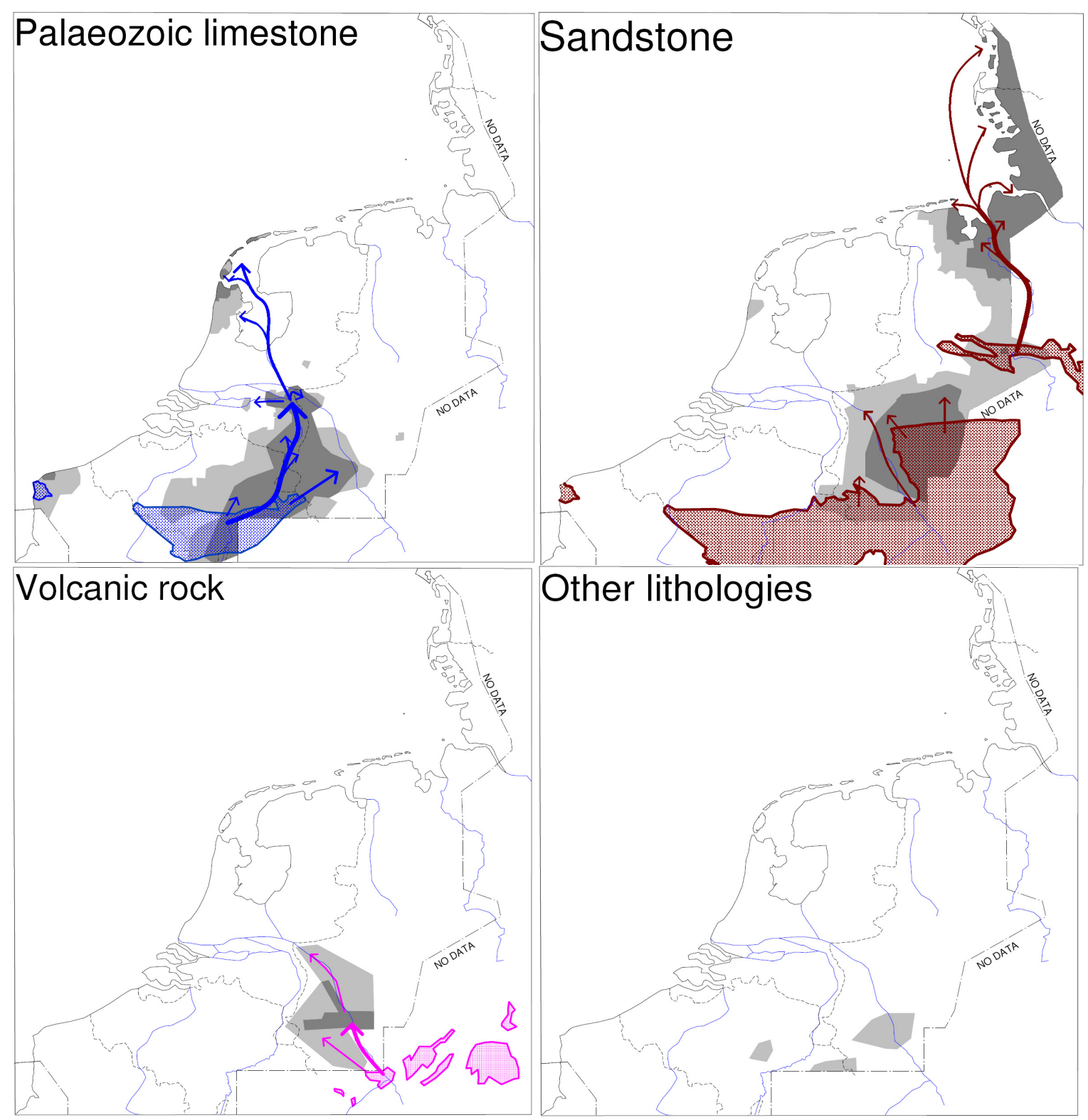

Figure 10. Occurrence of seventeenth- and eighteenth-century headstones in continental north-western Europe by lithology. Dark and light grey tones represent high and medium densities of headstones of a particular lithology. The southern polygons stand for areas with rock of the same lithology. Hypothesised trade routes are indicated.

As mentioned in the case of the Berwinne and Vesdre areas, local materials were used in the massifs. In the Meuse valley down to 's Hertogenbosch headstones in Palaeozoic limestone were established, originating from numerous quarries along the upper course of that river (Figure 7). The steles in North-Holland were also quarried from a uniform limestone, most probably from the Liège-Namur area, which is directly connected to the North-Holland cluster through the Meuse and Ijssel rivers (Figure 7). Materials used in the Marsh Islands are Belgian limestone in the Dutch islands, and sandstone originating from the Weserbergland in the German and Danish islands. However, local lore on the island Amrum suggests that sailors living on the island brought the headstones from 
Holland. ${ }^{66}$ A similar suggestion is also found in tourist information regarding the Danish island $\mathrm{R} \varnothing \mathrm{m} \emptyset$, although no evidence has yet been found to support it.

\section{Design and epigraphy}

Cruciform headstones obviously form a distinct group, usually referred to as grave crosses. ${ }^{67}$ These are generally linked to the Roman Catholic confession and tended not to be used by members of the Reformed Churches (especially by the Calvinists). ${ }^{68}$ The Catholic preference for the use of crosses on headstones, and for religious profession in general, is well known. ${ }^{69}$ By contrast, Protestants were rather reserved in using such a high symbol in the rather common context of headstones. There is one eighteenth-century instance in which the Dutch general Vlodrop, passing Sint-Truiden, ordered the destruction of a headstone in memory of one of his ancestors, because it had the shape of a cross. ${ }^{70}$ In contrast, on the northern Marsh Islands, half of the (protestant) headstones bear bible texts.

\section{Discussion}

The highest densities of headstones are found in the stone producing areas, and in regions to the north that follow the zones of influence of river transport along the Meuse, Rhine and Weser (Figure 4). Headstones are also present in the Boulonnais stony heights. From this high-density area to the north-west, there is a remarkably rapid decrease in headstone density.

The western area around Hainaut in which stones were produced is almost entirely devoid of headstones, as are the downstream Belgian Flanders provinces (including Ghent and Bruges) as well as Dutch Zeeland. One notable exception is a cemetery with Jewish headstones at Middelburg. Besides the possible influence of destructions in the source area, there was a marked preference for slabs in church walls, which exist both in the Tournaisis and the Antwerp area (Figure 7). ${ }^{71}$ Low headstone density in many towns of the south-western part of the study area may be related to iconoclastic or Napoleonic destructions of churchyards. ${ }^{72}$ Overall, however, the hypothesis that the low density of headstones in the lowlands is due to high transportation costs from the source areas remains valid given the absence of archaeological evidence of extensive and systematic destruction of headstones at such a scale (from Dunkirk to Münster).

The numerous headstones on Jewish cemeteries within the large area that is otherwise devoid of headstones (including Middelburg, Amsterdam and Groningen) reflects cultural influences that the Ashkenazi Jews brought from central Europe, as is evidenced by the

\footnotetext{
${ }^{66}$ Möller, Der Kirchhof in Nebel auf Amrum (note 9).

${ }^{67}$ Fischer, Die alten steinernen Grabkreuze im Kölner Raum (note 9).

${ }^{68} \mathrm{~J}$. P. Lensen and J. Nijssen, Croix, potales et chapelles au Pays de Visé - étude des témoins externes d'art religieux du Doyenné de Visé (Blégny, Dalhem et Visé), Visé, 1989.

${ }^{69}$ Fischer, Die alten steinernen Grabkreuze im Kölner Raum (note 9).

${ }^{70}$ B. W. Schijndel, Het geslacht Van Vlodrop in Brabant en Limburg, De Nederlandsche Leeuw: Maandblad van het Koninklijk Nederlandsch Genootschap voor Geslacht- en Wapenkunde 1969, 37-42.

${ }^{71}$ Own observations; KIK-IRPA (note 9).

${ }^{72}$ Moreaux, Quelques aspects de l'histoire funéraire (note 36).
} 
existence from the thirteenth to fifteenth centuries of tablets on Jewish cemeteries in Worms, Mainz or Prague. ${ }^{73}$

On the North Sea coast, headstones were concentrated in two isolated clusters, namely (1) North-Holland and the Dutch Marsh Islands and (2) the North-Frisian Islands up to Hamburg. This distribution is related to shipping and particularly whaling activities.

Prior to the nineteenth century, Holland imported a great deal of its stone from Belgium because natural hard stone was absent. This was the case not only for architectural use but also for (well-dated) gravestones. On the other hand, Holland had an important colonial trade. It was common for ships to carry shaped stones as ballast on their outbound journey. ${ }^{74}$ Particularly known is the case of the Batavia which carried 27 tonnes of building stones as ballast from Amsterdam to Java in $1629 .^{75}$ Some of these seafarers transported with them their own gravestones, and had them carved during their lifetime. ${ }^{76}$ This is particularly interesting as these slabs were already imported stone, generally composed of early Carboniferous limestone, used both for building purposes and for small monuments. At Nagasaki in Japan, for instance, there is an imported Dutch headstone dating back to $1787 .{ }^{77}$

Similarly, Arctic seamen, the whalers and especially their commanders carried building materials for their houses, as well as headstones from the Amsterdam and Bremen home ports to the islands from which they largely originated. Since the whalers of the Marsh Islands had a common attitude towards headstones, it is possible to group the various forms of funerary art on these islands into a common school, from the now empoldered island of Callantsoog in the west to Fanø in Denmark.

Concerning the overall temporal pattern evident in the database, the late establishment of headstones in the northern clusters indicates that the headstones were first prepared for the local population in the stony heights, where the first headstones date back to well before $1500 .^{78}$ The south-eastern locations peaked some 50 years later than the southwestern (in 1680, as compared to 1630), which shows that the tortuous course of the Meuse through the Ardennes massif made this region the hotspot of headstone production in North-West Europe. From the Ardennes, the innovation spread easily along the major rivers, but it took some time to reach the Marsh Islands. This delay was related both to distance and to cultural, socio-economic and religious differences. Finally, it is notable that the timing of the peaks in the erection of headstones in the seventeenth century

\footnotetext{
${ }^{73}$ O. Böcher, Der alte Judenfriedhof zu Worms, Neuss, 1984; F. Reuter and C. Wiesner, Der Judenfriedhof zu Worms, in Ein edler Stein sei sein Baldachin. Jüdische Friedhöfe in Rheinland-Pfalz (ed. Rhein-LahnKreis) (Rheinland-Pfalz, 1996); B. A. Vest, Der alte jüdische Friedhof in Mainz, Mainz, 2000; H. Volavkova, O. Muneles and T. Jakobovich, The Old Jewish Cemetery of Praha: A Guide Through the Cemetery, Prague, 1947.

${ }^{74}$ P. C. Buckland and J. Sadler, Ballast and building stone: a discussion, in D. Parsons, ed., Stone: Quarrying and Building in England, AD 43-1525, Chichester, 1990; J. N. Green, Maritime Archaeology: A Technical Handbook, London, 2000.

${ }^{75}$ R. Gould, Archaeology and the Social History of Ships, Cambridge, 2000.

${ }^{76}$ O. C. Nerong, Die Kirchhöfe Föhrs, 1909.

${ }^{77}$ M. Mioch, De Hollandsche Begraafplaats te Nagasaki, Kwartaalblad van het Centraal Bureau voor Genealogie 3 (1997).

${ }^{78}$ J. Nijssen, De oudste stenen grafkruisen van het Maasland, in A. Roeck, J. Theuwissen, S. Top and S. van den Eijnde, eds., Liber Amicorum Prof. dr. Jozef Van Haver, 1991, 263 - 273.
} 
contrasts with the situation in Britain and Ireland, where rapid growth in the establishment of headstones had to wait until the eighteenth century. ${ }^{79}$

Concerning the use of source materials, it is clear that Palaeozoic limestone was in widespread use as the preferred stone for carving, the highest densities occurring in the Belgian limestone belt at the northern fringe of the Ardennes. Sandstone is represented mainly by the headstones in the stony heights of Eifel and Siebengebirge, with a second concentration along the German North Sea coast. In the Cologne Bight, at some distance from the stony heights, a rich mix of various lithologies appears, with volcanics and sandstone from the nearby Mittelgebirge and Palaeozoic limestone from the Ardennes (Figure 10). Headstones in volcanic rock are located on or nearby the volcanic outcrops of the Eifel, and among volcanic rocks, there seems to be a preference for latite. Materials used in the stony heights and their surroundings are of local origin, as shown for example in the cases of Vesdre and Berwinne. Further, the establishment of headstones in areas along the Meuse, used to transport Palaeozoic limestone, is also obvious. At the end of the trade chain, in the Marsh islands, the northern and western clusters of headstones are related to the nearby streams: Meuse for the western area and Weser for the northern area. ${ }^{80}$ For the North-Frisian island Amrum, for instance, the hypothesis that the stones were of Belgian origin has been rejected. ${ }^{81}$ After all, if the northern headstones had been products imported through Holland, why then is the material different from that in the north-western cluster? Moreover, would the Dutch have brought wealthier headstones to these northern areas than those used in their own region? (Compare Figure 2 to Figure 8).

\section{Conclusions}

The Hercynian chain of the Rhenish-Eifel-Ardennes massif, its fringes marked by belts of limestone and sandstone, provided materials for the production and distribution of headstones in the more fertile, increasingly populous areas to the North. The trade in headstones, related to but distinct from that in building materials, clearly depended on local initiatives and displayed a highly uneven geography. As a result, the limestone belt between Tournai and Namur produced relatively few headstones, while in the NamurAachen section, evidence of an extremely rich production, traded on a large scale, has survived until the present day. The erection of headstones began within the immediate neighbourhood of the stone quarrying regions themselves, as shown in the cases of Berwinne and Vesdre, the latter workshop having an extremely well developed epigraphy.

Lithological variations account for the differential development of headstone patterns between the east and the west of the study area. The temporal analysis (Figure 9) shows that the headstones developed first on the stony heights, and that soon a local trade developed in which the Vesdre area provided headstones up to $50 \mathrm{~km}$ further north and in the Aachen area up to Köln. Then the Meuse trade brought similar types of headstones up to the centre and east of the Netherlands. Finally, the tablet culture developed on the North Sea fringes, and was characterised by two parallel foci in North Holland and in the Weser/eastern Marsh area. The former consisted of plainly executed Belgian Walloon

\footnotetext{
${ }^{79}$ Mytum, Popular attitudes to memory (note 13).

${ }^{80}$ Quedens, Die alten Grabsteine auf dem Amrumer Friedhof (note 9).

${ }^{81}$ Möller, Der Kirchhof in Nebel auf Amrum (note 9).
} 
limestone monuments (Figure 7). The latter, provided by the Weserbergland, were richly decorated, presenting Protestant bible citations (Figure 2). These monuments were not simply memorials for the dead, but were often also an exteriorisation of prevalent religious beliefs. Both Marsh Island groups formed isolated clusters at the extremes of the North Sea Bay and these concentrations are also related to shipping and whaling in the Arctic seas. The tablets were used for the upper class of this community. The similarity between, and grouping of, these two clusters of tablets on the Marsh Islands is not based on the role of particular quarries but rather reflects the impact of maritime trade on the North Sea.

It is likely that the spread of headstones to the northern part of the study area was hindered in the early part of the period under study by transportation costs, as well as by Protestant attitudes to the use of the cross as a symbol on graves. The increasing use of headstones in the Marsh Islands reflected the influence of whaling and the consequent development of coastal transport. The dominance in that area of tablet-shaped headstones also enabled potential religious objections to be bypassed.

This study has sought to provide a rigorous quantitative analysis of the distribution of headstones in the low countries, and represents an advance on Belonje's qualitative assessment. We have also considered in more detail regional patterns in the use of source materials, historical changes over the period and cultural/religious aspects of change. ${ }^{82}$ The analysis highlights the extent of a large-scale trade in stones across the region, cutting across significant political, religious and linguistic differences. Last but not least, we have highlighted the particular case of the headstones on the Marsh Islands, a unifying cultural element in this UNESCO world heritage area, reflecting the impact of maritime activity in this region between the sixteenth to eighteenth centuries. ${ }^{83}$

\section{Acknowledgements}

The late Jaak Nijssen (1926-2009) passed away writing out the manuscript, which aims at presenting the major findings of his life work. Special thanks are due to his widow Elza Vandenabeele for critical revision of successive versions of the manuscript. We also want to thank Jaak and Elza's children, Bart, Piet, Koen, Liesbet, Rik and Mieke for participation in a seemingly endless campaign of field visits to cemeteries across the Low Countries s.l. Furthermore, inspiring thoughts were offered by the wider headstone investigation community and particularly the international congresses on headstone research organised by Arbeitsgemeinschaft Denkmalforschung (Trebur, Germany) as well as Arbeitskreis für Klein- u. Flurdenkmalforschung (Linz, Austria). Numerous fruitful discussions were also held with members of LIKONA (Belgian Limburg Cercle of Natural History and Geology) and of the Société Royale Archéo-Historique de Visé (Belgium). The valuable comments by three anonymous reviewers and the strong editorial hand of Felix Driver greatly contributed to the final version of this paper.

\footnotetext{
${ }^{82}$ Belonje, Steenen Charters (note 6).

${ }^{83}$ L. Fischer and H. Waterbolk, Landschap en cultuurgeschiedenis van het Waddenzeegebied, in Wadden, Verhalend Landschap (ed. M. Bemelman) 14-39, 2005.
} 


\section{Biographies}

The late Dr. Jaak Nijssen (1926-2009) (Dr. Med. Vet, UGent) was a researcher on late mediaeval small monuments.

Prof. Dr. Jan Nyssen is a physical geographer with research interests in the interactions between humans and the environment. He holds a PhD from KULeuven (2001) and is currently at the Department of Geography, Ghent University, Belgium. 